ISSN 0853-8557

\title{
DAMPAK PETUGAS PENGATUR LALU LINTAS TERHADAP KINERJA SIMPANG 4 TAK BERSINYAL JALAN AGRO-BOUGENVILE (LEMBAH UGM), YOGYAKARTA
}

\author{
Verawanti $^{1}$, Prima Juanita Romadhona ${ }^{1}$ \\ ${ }^{1}$ Program Studi Teknik Sipil, Universitas Islam Indonesia, Yogyakarta \\ Email: verahny@gmail.com \\ ${ }^{2}$ Program Studi Teknik Sipil, Universitas Islam Indonesia, Yogyakarta \\ Email: prima_dhona@uii.ac.id
}

\begin{abstract}
The arrangement of peak traffic flow in unsignalized intersections usually carried out by illegal traffic wardens (PTR) and legal traffic wardens (PR). Additionally, traffic management implemented by PTR and PR only during peak hours. This research was executed in 4 unsignalized Intersection at Agro street - Bougenville street (Lembah UGM), Sleman. The high traffic volume without the arrangement at the intersection caused traffic jam, so the performance level decreased. This study aimed to determine the impact of PTR and PR and find out alternative solutions at the intersection. The methods for obtaining primary data were by surveying traffic volume data, vehicle speed data, queue length data, driving behaviours and geometry in the field. The data analysis in this study used VISSIM 9.0. The intersection condition without traffic management of wardens had delay as much as 21,93 seconds with level of service (LOS) C. Intersections management with PTR produced a value of intersection delay was 30,02 seconds with level of service (LOS) D. Intersections management with PR produced a value of intersection delay was 29,20 seconds with level of service (LOS) D. This result showed that the performance of the intersections in all conditions were worse conditions. The alternative solution in this research was traffic signal with average delay value was 30,31 seconds with level of service (LOS) D. Hopefully, management intersections with traffic signals could reduce accidents risk at intersections.
\end{abstract}

Key words : Illegal Traffic Wardens, Legal Traffic Wardens, Unsignalized Intersections, Level of Service, Delay

\section{PENDAHULUAN}

Fenomena kemacetan arus lalu lintas sering dijumpai pada persimpangan tak bersinyal, terutama di daerah perkotaan. Fenomena kemacetan ini dimanfaatkan oleh petugas pengatur lalu lintas untuk membantu mengatur lalu lintas supaya menjadi lancar. Petugas pengatur lalu lintas pada simpang tak bersinyal terdiri dari oknum pribadi selaku petugas tidak resmi (PTR) yang biasa disebut pak ogah dan polisi selaku petugas resmi (PR). The Strait Times dalam Nursalam dan Akhir (2016) menyebutkan bahwa PTR (illegal traffic wardens) adalah pengatur lalu lintas tidak resmi yang kebanyakan ditemukan di pertigaan ( $T$ - junctions), di putaran jalan ( $U-$ turns) dan persimpangan rel kereta api. Menurut Chopel (2006) dalam
Nursalam dan Akhir (2016), PTR (illegal traffic wardens) adalah pengatur jalan ilegal yang biasanya meminta upah di jalan atas jasanya mengatur lalu lintas. Kurangnya pemahaman PTR tentang pengaturan dan peraturan lalu lintas menyebabkan kemacetan bertambah parah akibat pengaturan lalu lintas yang salah (Yusuf, 2017). Pengaturan lalu lintas pada persimpangan dengan arus lalu lintas cukup tinggi juga diatur oleh petugas resmi (PR) yang sudah dibekali pengetahuan tentang pengaturan lalu lintas. Menurut Pemerintah Republik Indonesia (2009), terdapat dua lembaga resmi di Indonesia yang berperan dalam mengatur lalu lintas yaitu Petugas Dinas Perhubungan dan Polisi Lalu Lintas (Polantas). Salah satu simpang tak bersinyal yang terdapat PTR dan PR di 
Sleman adalah Simpang Jalan Agro - Jalan Bougenvile. Persimpangan Jalan Agro - Jalan Bougenvile merupakan salah satu simpang 4 lengan tak bersinyal di Daerah Sleman yang di lewati berbagai jenis kendaraan seperti sepeda motor, mobil, bus dan truk. Persimpangan ini adalah persimpangan yang tidak di atur dengan lampu pengatur lalu lintas, rambu atau tanda peringatan yang baik, sehingga memiliki resiko dalam memunculkan berbagai konflik pada titik titik pertemuan jalan tersebut. Tidak jauh dari area persimpangan ini terdapat kampus, wisata kuliner dan pertokoan. Volume lalu lintas tinggi tanpa adanya pengaturan lalu lintas, menyebabkan terjadinya kemacetan pada saat jam sibuk di hari kerja atau akhir pekan sehingga menyebabkan tingkat kinerja simpang menurun karena adanya tundaan dan antrean. Sehubungan dengan permasalahan di atas, maka diperlukan analisis yang dilakukan pada simpang Jalan Agro - Jalan Bougenvile, untuk mengetahui dampak petugas tidak resmi dan petugas resmi terhadap kinerja persimpangan tersebut dan mencari solusi yang dapat digunakan dalam mengatasi permasalahan yang terjadi.

Penelitian serupa telah dilakukan oleh $\mathrm{Al}$ Qadri (2006) yang menjelaskan tentang pengaruh petugas resmi dan petugas tidak resmi terhadap lalu lintas di persimpangan prioritas (studi kasus Simpang Kompas, Kabupaten Bekasi). Penelitian tersebut bertujuan untuk mengetahui kinerja dan perilaku arus lalu lintas persimpangan prioritas dengan adanya petugas resmi dan petugas tidak resmi dengan menghitung panjang antrian dan tundaan pada simpang berdasarkan survei di lapangan.

Penelitian tentang solusi terhadap simpang tidak bersinyal telah dilakukan oleh Anjanto dkk (2013), Bawangun dkk (2015), Sriharyani dan Hadijah (2015), Sriharyani dan Hadijah (2016), dan Sugiharti (2013) dengan menggunakan metode perhitungan Direktorat Jenderal Bina Marga (1997). Mereka telah meneliti pada simpang tidak bersinyal dengan kinerja buruk dan mengusulkan beberapa alternative solusi diantaranya pembangunan kanal, pemasangan rambu STOP dan YIELD, serta pelebaran jalan.

Selain itu, Saputro dkk (2018) dan Tahjudin (2017) juga melakukan penelitian tentang kajian simpang tiga tak bersinyal menjadi simpang bersinyal menggunakan permodelan Vissim. Pada penelitian tersebut dilakukan simulasi permodelan persimpangan secara akurat pada kondisi eksisting dan pemodelan dengan pemasangan APILL.

\section{SIMPANG TAK BERSINYAL}

Menurut Peraturan Pemerintah Nomor 43 Tahun 1993 tentang Prasarana dan Lalu Lintas Jalan, persimpangan merupakan pertemuan atau percabangan jalan, baik sebidang maupun yang tidak sebidang. Simpang merupakan suatu daerah umum, dimana dua arus jalan atau lebih bergabung atau berpotongan, termasuk fasilitas yang ada di sekitar jalan untuk pergerakan lalu lintas dalam daerah tersebut (Oglesby dan Hicks, 1990).

Simpang tak bersinyal merupakan pertemuan atau percabangan jalan yang tidak diatur dengan lampu lalu lintas (Morlok, 1988).

\section{Level of Services (LOS)}

Menurut Peraturan Menteri Nomor 96 Tahun 2015 tentang Pedoman Pelaksanaan Kegiatan Manajemen dan Rekayasa Lalu Lintas, klasifikasi tingkat pelayanan pada persimpangan adalah sebagai berikut.

1. Tingkat pelayanan A (kondisi tundaan $<5$ detik/kendaraan)

2. Tingkat pelayanan B (kondisi tundaan $>5$ $\operatorname{detik} /$ kendaraan)

3. Tingkat pelayanan $\mathrm{C}$ (kondisi tundaan antara $>15$ detik/kendaraan sampai 25 detik/kendaraan)

4. Tingkat pelayanan $\mathrm{D}$ (kondisi tundaan $>25$ detik/kendaraan sampai $\quad 40$ detik/kendaraan)

5. Tingkat pelayanan $\mathrm{E}$ (kondisi tundaan $>40$ detik/kendaraan sampai $\quad 60$ detik/kendaraan) 
6. Tingkat pelayanan $\mathrm{F}$ (kondisi tundaan $>60$ detik/kendaraan)

\section{PETUGAS PENGATUR LALU LINTAS}

Pengaturan lalu lintas oleh petugas telah ditetapkan dalam Pemerintah Republik Indonesia (2012), dimana pengaturan lalu lintas di jalan dengan menggunakan gerakan tangan, isyarat bunyi, isyarat cahaya dan alat bantu lainnya dalam keadaan tertentu.

Menurut Pemerintah Republik Indonesia (2009), terdapat dua lembaga resmi di Indonesia yang berperan dalam mengatur lalu lintas yaitu Petugas Dinas Perhubungan dan Polisi Lalu Lintas (Polantas). Kemacetan yang terjadi di simpang tak bersinyal, biasanya dimanfaatkan oleh petugas tidak resmi (PTR) untuk membantu mengatur lalu lintas supaya lancar. Tetapi, keberadaan PTR di persimpangan banyak menuai pro dan kontra bagi sebagian besar pengguna jalan. Hal tersebut disebabkan oleh kurangnya pengetahuan PTR terhadap pengaturan lalu lintas bisa menyebabkan kecelakaan pada pengguna jalan (Haryudi, 2013). Selain itu, perlakuan khusus PTR yaitu dengan memprioritaskan pengguna jalan yang memberikan uang sebagai imbalan juga memperparah kemacetan terjadi (Yusuf, 2017)

\section{PTV VISSIM}

Vissim atau Verkehr Stadten SIMulationsmodell yang berarti "Lalu Lintas di Kota-Model Simulasi” merupakan sebuah perangkat lunak pemodelan transportasi yang digunakan untuk menganalisis lalu lintas dan perpindahan dengan batas - batas yaitu jalur geometri, sinyal lalu lintas, komposisi kendaraan, perilaku pengemudi, stop line dan lain - lain. Vissim merupakan software yang dikembangkan oleh Planung Transport Verkehr AG (2016) di Karlsruhe, Jerman. Vissim digunakan untuk mengevaluasi bermacam - macam alternatif berdasarkan rekayasa transportasi dalam pengambilan keputusan yang lebih efektif dan efisien. Vissim juga dipilih untuk mengkalibrasi kondisi lalu lintas.
Validasi dalam VISSIM untuk volume kendaraan dapat dilakukan dengan menggunakan metode rumus statistik Geoffrey E. Havers (GEH). GEH adalah rumus statistik hasil modifikasi dari rumus Chi-squared. Rumus statistik GEH dihitung untuk pergerakan simpang dan koleksi data melalui atribut yang ditentukan pengguna. Rumus statistik GEH digunakan untuk membandingkan dua volume lalu lintas yaitu volume kendaraan observasi dan volume kendaraan yang dimodelkan. Rumus yang digunakan dalam validasi $G E H$ adalah sebagai berikut.

$G E H=\sqrt{\frac{2(M-C)^{2}}{M+C}}$

dengan:

$\mathrm{M}=$ Volume kendaraan yang dimodelkan di VISSIM

$\mathrm{C}=$ Volume kendaraan yang dihitung di lapangan

Hasil perhitungan rumus statistik $G E H$ mempunyai ketentuan sebagai berikut.

1. Hasil $G E H<5$, kondisi permodelan memenuhi dan tidak ada masalah.

2. Hasil GEH diantara $5-10$, kondisi permodelan perlu di cek ulang.

3. Hasil $G E H>10$, kondisi permodelan tidak memenuhi dan ada masalah.

\section{METODE PENELITIAN}

Tahap - tahap dalam penelitian ini adalah tahap persiapan, tahap pengumpulan data dan tahap analisis data. Tahap persiapan dimulai dengan mengkaji permasalahan yang ada dan mencari referensi penelitian serupa yang bisa dijadikan studi literatur. Tahap pengumpulan data, dilakukan dengan pengambilan data primer berupa survei di lapangan secara langsung yaitu volume kendaraan diperoleh dengan melakukan perhitungan jumlah kendaraan yang melintas pada setiap lengan di persimpangan. Setiap lengan terdapat tiga orang surveyor yang bertugas menghitung jumlah kendaraan berat, kendaraan ringan dan motor yang belok kiri, lurus dan kanan. Kecepatan kendaraan diperoleh dengan cara manual yaitu menghitung jarak tempuh dibagi 
waktu tempuh menggunakan bantuan stopwatch. Panjang antrean dilakukan dengan cara mengukur panjang antrean kendaraan dari depan muka simpang sampai kendaraan paling belakang pada antrean kendaraan. Driving behaviors dilakukan dengan dua tipe, yaitu mengukur jarak kendaraan dari depan sampai belakang dan dari samping kendaraan yang berhenti maupun sedang melintas dijalan, dan geometri simpang dengan mengukur lebar tiap lajur dan median yang ada di setiap lengan Simpang Jalan Agro Bougenville. Waktu pengambilan data primer dalam penelitian ini dilakukan selama 3 hari kerja yaitu Senin untuk menentukan jam sibuk, Selasa dengan kondisi tidak ada petugas tidak resmi dan Kamis dengan kondisi ada petugas tidak resmi, selama 12 jam dari pukul 06.00 WIB - 18.00 WIB. Pengambilan data sekunder berupa data jumlah penduduk Kabupaten Sleman di Badan Pusat Statistik Daerah Istimewa Yogyakarta. Tahap analisis data, tahap ini dilakukan setelah data yang dikumpulkan sudah lengkap. Analisis data dengan menghitung waktu siklus menggunakan Manual Kapasitas Jalan Indonesia (MKJI 1997) dan permodelan program PTV VISSIM dengan kondisi tanpa pengaturan petugas, dengan PTR (sejumlah satu orang PTR), dengan PR (sejumlah satu orang PR), serta menggunakan sinyal lalu lintas. Parameter output permodelan program VISSIM adalah nilai tundaan (delay) dan panjang antrian. Lokasi penelitian yang digunakan dalam penelitian ini dapat dilihat pada Gambar 1 berikut.

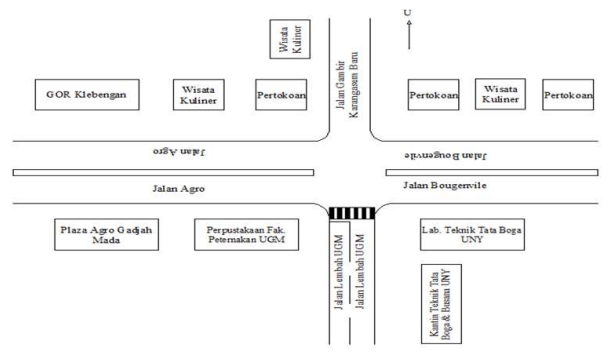

Gambar 1 Sketsa Simpang Jalan Agro Bougenville (Lembah UGM)

\section{ANALISIS DAN PEMBAHASAN}

Analisis perhitungan waktu siklus pada penelitian ini berdasarkan Direktorat Jenderal Bina Marga (1997).

\section{Waktu Siklus Simpang Bersinyal}

Gambar diagram untuk waktu sinyal pada Simpang Jalan Agro - Bougenville dapat dilihat pada Gambar 2 berikut.

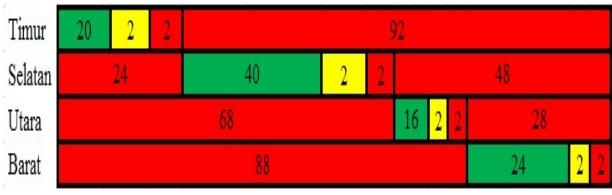

Gambar 2 Diagram Waktu Siklus Simpang Jalan Agro - Bougenville

Validasi Menggunakan GEH Pada VISSIM

Hasil validasi menggunakan $G E H$ pada VISSIM masing - masing kondisi pengaturan dapat dilihat pada Tabel 1, Tabel 2, Tabel 3, dan Tabel 4 berikut.

\section{Tanpa Pengaturan Petugas}

Dari hasil perhitungan menunjukkan hasil $<5$, dimana nilai tersebut menunjukkan kondisi terpenuhi dan tidak ada masalah.

Tabel 1 Validasi Menggunakan GEH Kondisi tanpa Pengaturan Petugas

\begin{tabular}{|c|c|c|c|c|}
\hline $\begin{array}{c}\text { Lenga } \\
\mathrm{n}\end{array}$ & $\begin{array}{c}\text { Volume } \\
\text { Eksisting } \\
(\text { Kend/Ja } \\
\mathrm{m})\end{array}$ & $\begin{array}{c}\text { Volume } \\
\text { VISSIM } \\
(\text { Kend/Ja } \\
\mathrm{m})\end{array}$ & $\begin{array}{c}G E \\
H\end{array}$ & $\begin{array}{c}\text { Keteranga } \\
\mathrm{n}\end{array}$ \\
\hline Barat & 2158 & 2113 & 0,97 & Valid \\
\hline Utara & 709 & 680 & 1,10 & Valid \\
\hline Timur & 1925 & 1896 & 0,66 & Valid \\
\hline $\begin{array}{c}\text { Selata } \\
\mathrm{n}\end{array}$ & 2414 & 2187 & 4,73 & Valid \\
\hline
\end{tabular}




\section{Pengaturan dengan Petugas Tidak Resmi}

Dari hasil perhitungan menunjukkan hasil $<5$, dimana nilai tersebut menunjukkan kondisi terpenuhi dan tidak ada masalah.

Tabel 2 Validasi Menggunakan GEH Kondisi dengan PTR

\begin{tabular}{|c|c|c|c|c|}
\hline $\begin{array}{c}\text { Lenga } \\
\mathrm{n}\end{array}$ & $\begin{array}{c}\text { Volume } \\
\text { Eksisting } \\
(\text { Kend/Ja } \\
\mathrm{m})\end{array}$ & $\begin{array}{c}\text { Volume } \\
\text { VISSIM } \\
(\text { Kend/Ja } \\
\mathrm{m})\end{array}$ & $\begin{array}{c}G E \\
H\end{array}$ & $\begin{array}{c}\text { Keteranga } \\
\mathrm{n}\end{array}$ \\
\hline Barat & 2091 & 2060 & 0,68 & Valid \\
\hline Utara & 442 & 421 & 1,01 & Valid \\
\hline Timur & 2040 & 2027 & 0,29 & Valid \\
\hline $\begin{array}{c}\text { Selata } \\
\mathrm{n}\end{array}$ & 2835 & 2577 & 4,96 & Valid \\
\hline
\end{tabular}

\section{Pengaturan dengan Petugas Resmi}

Dari hasil perhitungan menunjukkan hasil $<5$, dimana nilai tersebut menunjukkan kondisi terpenuhi dan tidak ada masalah.

Tabel 3 Validasi Menggunakan GEH Kondisi dengan PR

\begin{tabular}{|c|c|c|c|c|}
\hline $\begin{array}{c}\text { Lenga } \\
\mathrm{n}\end{array}$ & $\begin{array}{c}\text { Volume } \\
\text { Eksisting } \\
(\text { Kend/Ja } \\
\mathrm{m})\end{array}$ & $\begin{array}{c}\text { Volume } \\
\text { VISSIM } \\
(\text { Kend/Ja } \\
\mathrm{m})\end{array}$ & $\begin{array}{c}G E \\
H\end{array}$ & $\begin{array}{c}\text { Keteranga } \\
\mathrm{n}\end{array}$ \\
\hline Barat & 2273 & 2243 & 0,63 & Valid \\
\hline Utara & 1609 & 1483 & 3,20 & Valid \\
\hline Timur & 1797 & 1772 & 0,59 & Valid \\
\hline $\begin{array}{c}\text { Selata } \\
\mathrm{n}\end{array}$ & 1442 & 1427 & 0,40 & Valid \\
\hline
\end{tabular}

\section{Pengaturan dengan Sinyal Lalu Lintas}

Dari hasil perhitungan menunjukkan hasil $<5$, dimana nilai tersebut menunjukkan kondisi terpenuhi dan tidak ada masalah.

Tabel 4 Validasi Menggunakan GEH Kondisi dengan Sinyal Lalu Lintas

\begin{tabular}{|c|c|c|c|c|}
\hline $\begin{array}{c}\text { Lenga } \\
\mathrm{n}\end{array}$ & $\begin{array}{c}\text { Volume } \\
\text { Eksisting } \\
(\text { Kend/Ja } \\
\mathrm{m})\end{array}$ & $\begin{array}{c}\text { Volume } \\
\text { VISSIM } \\
(\text { Kend/Ja } \\
\mathrm{m})\end{array}$ & $\begin{array}{c}G E \\
H\end{array}$ & $\begin{array}{c}\text { Keteranga } \\
\mathrm{n}\end{array}$ \\
\hline Barat & 2091 & 2056 & 0,77 & Valid \\
\hline Utara & 442 & 421 & 1,01 & Valid \\
\hline Timur & 2040 & 2014 & 0,58 & Valid \\
\hline $\begin{array}{c}\text { Selata } \\
\mathrm{n}\end{array}$ & 2835 & 2770 & 1,23 & Valid \\
\hline
\end{tabular}

\section{Alternatif Solusi Perbaikan Kinerja Simpang}

Hasil analisis menggunakan VISSIM dengan sinyal lalu lintas dapat dilihat pada Tabel 5 berikut.

Tabel 5 Hasil Analisis Menggunakan VISSIM dengan Sinyal Lalu Lintas

\begin{tabular}{|c|l|c|c|c|c|}
\hline \multirow{2}{*}{$\begin{array}{c}\mathrm{N} \\
\mathrm{o}\end{array}$} & \multicolumn{2}{|c|}{ Parameter } & \multicolumn{4}{|c|}{ Lengan } \\
\cline { 3 - 6 } & $\begin{array}{c}\text { Bara } \\
\mathrm{t}\end{array}$ & $\begin{array}{c}\text { Uta } \\
\text { ra }\end{array}$ & $\begin{array}{c}\text { Tim } \\
\text { ur }\end{array}$ & $\begin{array}{c}\text { Selat } \\
\text { an }\end{array}$ \\
\hline 1 & Tundaan (detik) & $\begin{array}{c}29,9 \\
4\end{array}$ & $\begin{array}{c}41,8 \\
9\end{array}$ & $\begin{array}{c}31,5 \\
1\end{array}$ & 17,92 \\
\hline 2 & $\begin{array}{l}\text { Panjang Antrean } \\
\text { (meter) }\end{array}$ & $\begin{array}{c}110, \\
37\end{array}$ & $\begin{array}{c}13,5 \\
9\end{array}$ & $\begin{array}{c}27,2 \\
7\end{array}$ & $\begin{array}{c}162,9 \\
2\end{array}$ \\
\hline 3 & Tingkat Pelayanan & $\mathrm{D}$ & $\mathrm{E}$ & $\mathrm{D}$ & $\mathrm{C}$ \\
\hline
\end{tabular}

Tabel 5 menunjukkan hasil analisis menggunakan VISSIM dengan sinyal lalu lintas dengan nilai tundaan rata - rata seluruh simpang adalah 30,31 detik, sehingga tingkat pelayanan simpang dengan sinyal lalu lintas adalah D.

Perbaikan kinerja simpang menggunakan sinyal lalu lintas pada simpang tak bersinyal dengan arus lalu lintas yang tinggi dapat mengurangi resiko terjadinya kecelakaan di persimpangan.

Rekapitulasi Hasil Analisis Masing Masing Kondisi Pengaturan

Tabel 6 menunjukkan hasil analisis menggunakan VISSIM masing - masing kondisi pengaturan. Kondisi pengaturan simpang tidak diatur oleh petugas menghasilkan tundaan sebesar 21,93 detik, panjang antrean 75,83 meter dan tingkat pelayanan simpang adalah C. Kondisi pengaturan simpang dengan diatur oleh PTR menghasilkan tundaan sebesar 30,02 detik, panjang antrean 76,94 meter dan tingkat pelayanan simpang adalah D. Kondisi pengaturan simpang diatur oleh PR menghasilkan tundaan sebesar 29,20 detik, panjang antrean 109,94 meter dan tingkat pelayanan adalah D. Kondisi pengaturan simpang diatur oleh sinyal lalu lintas menghasilkan tundaan sebesar 30,31 detik, panjang antrean 78,54 meter dan tingkat pelayanan simpang adalah $\mathrm{D}$. 
Tabel 6 Rekapitulasi Hasil Analisis Menggunakan VISSIM Masing - Masing Kondisi Pengaturan

\begin{tabular}{|c|c|c|c|c|c|c|c|}
\hline \multirow{3}{*}{ No } & \multirow{3}{*}{\multicolumn{2}{|c|}{ Kondisi Pengaturan }} & \multicolumn{5}{|c|}{ Parameter } \\
\hline & & & \multicolumn{2}{|c|}{ Tundaan } & \multicolumn{2}{|c|}{ Panjang Antrean } & \multirow{2}{*}{$\begin{array}{c}\text { Tingkat } \\
\text { Pelayanan }\end{array}$} \\
\hline & & & (detik) & $\begin{array}{c}\text { Perbedaan } \\
(\%)\end{array}$ & (meter) & $\begin{array}{c}\text { Perbedaan } \\
(\%)\end{array}$ & \\
\hline 1 & \multirow{3}{*}{ Eksisting } & Tanpa Petugas & 21,93 & 0 & 75,83 & 0 & $\mathrm{C}$ \\
\hline 2 & & Dengan PTR & 30,02 & $-36,89$ & 76,94 & $-1,46$ & $\mathrm{D}$ \\
\hline 3 & & Dengan PR & 29,20 & $-33,15$ & 109,94 & $-44,98$ & $\mathrm{D}$ \\
\hline 4 & Alternatif Solusi & Dengan Sinyal & 30,31 & $-38,21$ & 78,54 & $-3,57$ & D \\
\hline
\end{tabular}

\section{Pembahasan}

Analisis yang dilakukan dengan masing masing kondisi pengaturan menghasilkan tundaan di atas 15 detik dengan tingkat pelayanan $\mathrm{C}$ dan $\mathrm{D}$.

\section{Perbandingan Nilai Tundaan}

Grafik perbandingan nilai tundaan masing masing kondisi pengaturan dapat dilihat pada Gambar 3 berikut.

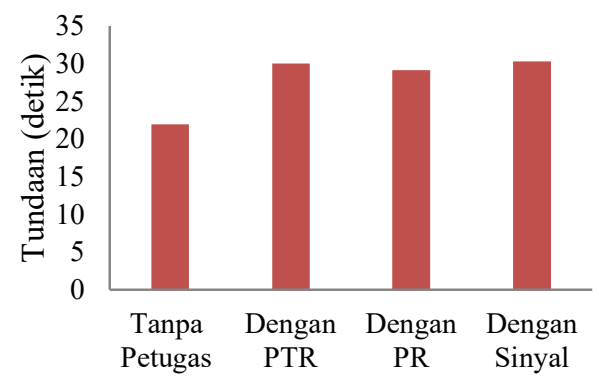

Kondisi Pengaturan

Gambar 3 Grafik Perbandingan Nilai Tundaan

Gambar 3 menunjukkan kondisi pengaturan simpang dengan diatur oleh PTR, PR dan sinyal lalu lintas menggunakan VISSIM memiliki perbedaan nilai tundaan yang cukup signifikan jika dibandingkan dengan kondisi tanpa pengaturan. Kondisi pengaturan simpang dengan diatur oleh PTR mengalami perbedaan nilai tundaan sebesar $36,89 \%$ jika dibandingkan dengan tanpa pengaturan. Kondisi pengaturan simpang dengan diatur oleh PR mengalami perbedaan nilai tundaan sebesar 33,15\% jika dibandingkan dengan tanpa pengaturan. Kondisi pengaturan simpang dengan diatur oleh sinyal lalu lintas mengalami perbedaan nilai tundaan sebesar $38,21 \%$ jika dibandingkan dengan tanpa pengaturan.

Kondisi simpang tanpa pengaturan menghasilkan nilai tundaan yang kecil, tetapi resiko yang dihasilkan cukup besar. Kondisi tanpa pengaturan akan menyebabkan resiko kecelakaan lebih tinggi pada daerah konflik di persimpangan jika dibandingkan dengan kondisi diatur oleh petugas. Kondisi simpang dengan diatur oleh PTR menghasilkan nilai tundaan $<40$ detik, tetapi pengaturan lalu lintas yang tidak jelas bisa mengakibatkan kecelakaan di persimpangan. Kondisi pengaturan dengan diatur oleh PR menghasilkan tundaan sedikit lebih baik dibandingkan dengan diatur oleh PTR. Pengaturan lalu lintas yang lebih rapi dan teratur bisa mengurangi resiko kecelakaan, tetapi PR tidak selalu ada di persimpangan. Alternatif solusi perbaikan kinerja simpang yang ditawarkan adalah sinyal lalu lintas, karena sinyal lalu lintas di nilai mempunyai manfaat dalam mengurangi resiko kecelakan akibat konflik di persimpangan dengan meniadakan konflik antar lengan dan sinyal lalu lintas selalu ada di lapangan.

Berdasarkan Pemerintah Republik Indonesia (2015), tingkat pelayanan simpang terbaik pada penelitian ini adalah saat kondisi simpang tanpa pengaturan dengan level of service (LOS) C, diatur petugas resmi dengan level of service (LOS) D dan diatur petugas tidak resmi dengan level of service (LOS) D. 
Hasil penelitian terdahulu yang dilakukan oleh Al Qadri (2006), dengan judul penelitian "Pengaruh Petugas Resmi dan Petugas Tidak Resmi Terhadap Lalu Lintas di Persimpangan Prioritas (Studi Kasus : Simpang Kompas Kabupaten Bekasi) menjelaskan bahwa kinerja persimpangan terbaik adalah saat kondisi simpang diatur oleh petugas resmi, tanpa pengatur dan dengan petugas tidak resmi. Tabel rekapitulasi nilai tundaan dengan masing - masing kondisi pengaturan pada persimpangan dapat dilihat pada Tabel 7 berikut.

Tabel 7 Rekapitulasi Nilai Tundaan Masing - Masing Kondisi Pengaturan Penelitian Terdahulu dan Penulis

\begin{tabular}{|c|l|c|c|}
\hline \multirow{2}{*}{ No } & \multirow{2}{*}{$\begin{array}{c}\text { Kondisi } \\
\text { Pengaturan }\end{array}$} & \multicolumn{2}{|c|}{ Tundaan (detik) } \\
\cline { 3 - 4 } & & Al Qadri & Penulis \\
\hline 1 & Tanpa Pengaturan & 30,10 & 21,93 \\
\hline 2 & Dengan PTR & 27,03 & 30,02 \\
\hline 3 & Dengan PR & 25,80 & 29,20 \\
\hline 4 & Dengan Sinyal & - & 30,31 \\
\hline
\end{tabular}

Tabel 7 menunjukkan bahwa peneliti terdahulu yaitu Al Qadri hanya meninjau tiga kondisi pengaturan pada simpang yaitu dengan diatur oleh petugas resmi, tanpa pengaturan dan diatur oleh petugas resmi, tetapi tidak meninjau kondisi pengaturan simpang menggunakan sinyal lalu lintas. Kondisi simpang tanpa pengaturan petugas pada penelitian Al Qadri (2006) menghasilkan tingkat pelayanan D. Kondisi dengan pengaturan PTR menghasilkan tingkat pelayanan $\mathrm{D}$ dan menunjukkan penurunan nilai tundaan sebesar 10,20\% jika dibandingkan dengan kondisi tanpa pengaturan petugas. Kondisi pengaturan oleh PR menghasilkan tingkat pelayanan D dan menunjukkan penurunan nilai tundaan sebesar $14,28 \%$ jika dibandingkan dengan kondisi tanpa pengaturan petugas. Nilai tingkat pelayanan simpang pada penelitian $\mathrm{Al}$ Qadri (2006) sama - sama menunjukkan nilai $\mathrm{D}$, dengan nilai tundaan berkisar antara 25 detik - 40 detik/kendaraan. Penelitian Al Qadri (2006) menunjukkan bahwa kinerja persimpangan terbaik adalah diatur oleh petugas resmi, kemudian diatur oleh petugas tidak resmi dan terakhir tanpa pengaturan.

Penelitian yang dilakukan penulis (2019) meninjau kondisi tanpa pengaturan, dengan petugas tidak resmi, dengan petugas resmi dan menggunakan sinyal lalu lintas sebagai alternatif solusi perbaikan kinerja simpang. Penelitian ini menunjukkan kondisi tanpa pengaturan dengan tingkat pelayanan $\mathrm{C}$. Kondisi dengan pengaturan PTR menghasilkan tingkat pelayanan $\mathrm{D}$ dan menunjukkan kenaikan nilai tundaan sebesar $36,89 \%$ jika dibandingkan dengan kondisi tanpa pengaturan petugas. Kondisi dengan pengaturan $P R$ menghasilkan tingkat pelayanan $\mathrm{D}$ dan menunjukkan kenaikan nilai tundaan sebesar 33,15\% jika dibandingkan dengan tanpa pengaturan petugas. Pengaturan dengan sinyal lalu lintas menghasilkan tingkat pelayanan D dan menunjukkan kenaikan nilai tundaan sebesar $38,21 \%$ jika dibandingkan dengan tanpa pengaturan petugas. Pada penelitian ini tingkat pelayanan simpang menunjukkan nilai $\mathrm{C}$ dan $\mathrm{D}$, dengan kinerja persimpangan yang terbaik adalah saat tanpa pengaturan petugas, kemudian dengan diatur petugas resmi dan terakhir dengan diatur petugas tidak resmi.

\section{KESIMPULAN DAN SARAN}

\section{Kesimpulan}

Berdasarkan hasil analisis menggunakan VISSIM terhadap kinerja simpang, maka dapat disimpulkan beberapa hal berikut.

1. Kinerja simpang empat tak bersinyal Jalan Agro - Jalan Bougenville tanpa pengaturan petugas manapun menghasilkan nilai tundaan simpang yaitu 21,93 detik dengan tingkat pelayanan $\mathrm{C}$. Kondisi simpang tanpa pengaturan menghasilkan nilai tundaan yang kecil, tetapi resiko yang dihasilkan cukup besar. Kondisi tanpa pengaturan akan menyebabkan resiko kecelakaan lebih tinggi pada daerah konflik di persimpangan jika dibandingkan dengan kondisi diatur oleh petugas.

2. Kinerja simpang empat tak bersinyal Jalan Agro - Jalan Bougenville dengan adanya 
petugas tidak resmi menghasilkan nilai tundaan simpang yaitu 30,02 detik dengan tingkat pelayanan D. Kondisi simpang dengan diatur oleh PTR menghasilkan nilai tundaan $<40$ detik, tetapi pengaturan lalu lintas yang tidak jelas bisa mengakibatkan kecelakaan di persimpangan.

3. Kinerja simpang empat tak bersinyal Jalan Agro - Jalan Bougenville dengan adanya petugas resmi menghasilkan nilai tundaan simpang yaitu 29,20 detik dengan tingkat pelayanan D. Kondisi pengaturan dengan diatur oleh PR menghasilkan tundaan sedikit lebih baik dibandingkan dengan diatur oleh PTR. Pengaturan lalu lintas yang lebih rapi dan teratur bisa mengurangi resiko kecelakaan, tetapi PR tidak selalu ada di persimpangan.

4. Kinerja simpang empat tak bersinyal Jalan Agro - Jalan Bougenville dengan alternatif solusi sinyal lalu lintas menghasilkan nilai tundaan simpang yaitu 30,31 detik dengan tingkat pelayanan D. Alternatif solusi menggunakan sinyal lalu lintas dipilih karena sinyal lalu lintas di nilai mempunyai manfaat dalam mengurangi resiko kecelakan akibat konflik di persimpangan dengan meniadakan konflik antar lengan.

\section{Saran}

Saran yang dapat diberikan berdasarkan hasil penelitian ini adalah sebagai berikut.

1. Penelitian selanjutnya dapat meninjau arus lalu lintas jalan minor pada lengan barat dan lengan timur di Simpang Jalan Agro Bougenville dengan koordinasi sinyal karena arus lalu lintas di lengan tersebut cukup banyak.

2. Penelitian ini dapat dikembangkan dengan variasi hari penelitian di Simpang Jalan Agro - Bougenville.

3. Penelitian selanjutnya dapat menggunakan pendekatan gap time yaitu dengan menghitung waktu celah kendaraan di lapangan secara langsung.
4. Penelitian selanjutnya perlu dimodelkan dengan kondisi waktu penelitian pada hari dan jam yang sama serta volume lalu lintas yang sama agar bisa dibandingkan.

\section{DAFTAR PUSTAKA}

Al Qadri, M. (2006). Pengaruh Petugas Resmi dan Petugas Tidak Resmi Terhadap Lalu Lintas di Persimpangan Prioritas (Studi Kasus : Simpang Kompas Kabupaten Bekasi). Tesis. (Tidak Diterbitkan). Universitas Gadjah Mada. Yogyakarta.

Anjanto, A.V., Pradipta, R.R., Sulistio, H., dan Bowoputro, H. (2013). Kajian Perbaikan Kinerja Lalu Lintas di Koridor Gerbang Perumahan Sawojajar Kota Malang. Jurnal Rekayasa Sipil. Vol. 7 No. 3 - 2013 ISSN 1978 - 5658. Malang.

Bawangun, V., Sendow, T.K., dan Elisabeth, L. (2015). Analisis Kinerja Simpang Tak Bersinyal Untuk Simpang Jalan W.R. Supratman dan Jalan B.W. Lapian di Kota Manado. Jurnal Sipil Statik Vol. 3 No. 6 : 422 - 434. Manado.

Direktorat Jenderal Bina Marga. (1997). Manual Kapasitas Jalan Indonesia (MKJI). Penerbit Departemen Pekerjaan Umum. Jakarta.

Haryudi. (2013). Pak ogah marak, Tol Ciawi rawan kecelakaan dan kejahatan. SINDONews.(https://metro.sindonews.c om/read/702639/31/pak-ogah-marak-tolciawi-rawan-kecelakaan-dan-kejahatan1357040448. Diakses 15 Agustus 2018).

Morlok, E.K. (1988). Pengantar Teknik dan Perencanaan Transportasi. Erlangga. Jakarta.

Nursalam dan Akhir, M. (2016). Persepsi Masyarakat Terhadap Eksistensi Pak Ogah. Jurnal Equilibrium Pendidikan Sosiologi. Vol. III No. 2 : 224. Makassar

Oglesby, C.H. dan Hicks, R.G. (1990). Teknik Jalan Raya. Terjemahan oleh Purwo Setianto. 1999. Erlanggan. Jakarta. 
Planung Transport Verkehr AG. (2016). VISSIM 9.0-11 User Manual. Karlsruhe.

Pemerintah Republik Indonesia. (2012). Peraturan Kepala Kepolisian Negara Republik Indonesia Nomor 10 Tahun 2012 tentang Pengaturan Lalu Lintas Dalam Keadaan Tertentu dan Penggunaan Jalan Selain Untuk Kegiatan Lalu Lintas. Sekretariat Negara. Jakarta.

Pemerintah Republik Indonesia. (2015). Peraturan Menteri Nomor 96 Tahun 2015 tentang Pedoman Pelaksanaan Kegiatan Manajemen dan Rekayasa Lalu Lintas. Sekretariat Negara. Jakarta.

Pemerintah Republik Indonesia. (1993). Peraturan Pemerintah Nomor 43 Tahun 1993 tentang Prasarana dan Lalu Lintas Jalan. Sekretariat Negara. Jakarta.

Pemerintah Republik Indonesia. (2009). Undang - Undang Nomor 22 Tahun 2009 tentang Lalu Lintas dan Angkutan Jalan. Sekretariat Negara. Jakarta.

Saputro, dkk. (2018). Kajian Simpang Tiga Tak Bersinyal Kariangau KM. 5,5 Kelurahan Karang Joang Balikpapan Utara Menggunakan Permodelan Vissim menjadi Simpang Bersinyal. Jurnal Teknologi Terpadu. Vol. 6 No. 1. Balikpapan.

Sriharyani, L. Dan Hadijah, I. (2015). Analisis Kinerja Persimpangan Tanpa Lampu Lalu Lintas (Studi Persimpangan Pasar Way Jepara) Kabupaten Lampung Timur. Jurnal Tapak Vol. 4 No. 2 ISSN 2089-2098. Lampung.

Sriharyani, L. Dan Hadijah, I. (2016). Analisis Kinerja Simpang Tidak Bersinyal Kota Metro (Studi Kasus Persimpangan Jalan, Ruas Jalan Jend. Sudirman, Jalan Sumbawa, Jalan Wijaya Kusuma dan Jalan Inspeksi). Jurnal Tapak Vol. 6 No. 1 ISSN 2089-2098. Lampung

Sugiharti, P. (2013). Analisis Kinerja Simpang Tak Bersinyal (Studi Kasus : Simpang 3 Tak Bersinyal Jl. Raya Seturan
- Jl. Raya Babarsari - Jl. Kledokan, Depok, Sleman, Yogyakarta). Proceeding Konferensi Nasional Teknik Sipil 7. Surakarta.

Tahjudin, I. (2017). Pemodelan Simpang Tak Bersinyal Menjadi Simpang Bersinyal Menggunakan Software Vissim. Tugas Akhir. (Tidak Diterbitkan). Universitas Muhammadiyah Yogyakarta. Yogyakarta.

Yusuf, Y. (2017). Begini Jadinya Kalau Pak Ogah yang Atur Lalu Lintas di DKI. SINDONews.(https://metro.sindonews.c om/read/1225650/170/begini-jadinyakalau-pak-ogah-yang-atur-lalu-lintas-didki-1501490199. Diakses 9 Agustus 2018 